\title{
MEASUREMENT OF SMALL QUANTITIES OF INSULIN-LIKE ACTIVITY WITH RAT ADIPOSE TISSUE. IV. SERUM INSULIN-LIKE ACTIVITY AND TUMOR INSULIN CONTENT IN PATIENTS WITH FUNCTIONING ISLET-CELL TUMORS *
}

\author{
By JURGEN STEINKE, J. STUART SOELDNER, $\dagger$ AND ALBERT E. RENOLD $\ddagger$ \\ (From the Baker Clinic Research Laboratory, Department of Medicine, \\ Harvard Medical School, Boston, Mass.)
}

(Submitted for publication January 31, 1963 ; accepted April 24, 1963)

A clinical review of 766 cases of islet-cell tumors reported up to 1958 has recently been published (1), and approximately 100 additional case reports have appeared in the literature since then. There have been, however, few studies of serum insulin or serum insulin-like activity (ILA) in such patients, and only scattered reports of extractable insulin content in islet-cell tumors.

This report describes preoperative measurements of serum ILA in 23 patients with histologically confirmed islet-cell tumors and postoperative, additional measurements in 14 . In several patients, multiple serum samples were available. Data are also presented on the preoperative changes in serum ILA after glucose infusion in 6 patients. Islet-cell tumor tissue from 10 patients was available for insulin extraction and measurement. In addition, specimens of adjacent pancreas and metastatic tumor tissue could be obtained in some instances. For comparison, the same extraction methods were applied to pancreas obtained at autopsy from nondiabetic and from youth-onset and maturity-onset diabetic patients.

\section{MATERIALS AND METHODS}

In all 23 patients studied, the clinical diagnosis of isletcell tumor was confirmed by histological examination of the tumor tissue. Specimens and patient histories were

* Supported in part by a grant-in-aid from the Adler Foundation, Inc., Rye, N. Y.; The John A. Hartford Foundation, Inc., New York, N. Y.; Eli Lilly and Company, Indianapolis, Ind.; and U. S. Public Health grant 8M01-FR-31-03.

† Recipient of U. S. Public Health Service training grant 2A-5077-C5.

$\ddagger$ Present address: Institut de Biochimie Clinique, University of Geneva, Switzerland. provided through the courtesy of the attending physicians. ${ }^{1}$ Case reports concerning 4 patients of the present series have been published (2-4). Preoperatively, up to 6 serum samples were obtained in each of the 23 patients, either in the fasting state or during hypoglycemia. Fasting serum samples were also obtained 7 days after surgery or later, but only in patients who did not receive insulin treatment. Two patients died in the immediate postoperative period, 3 received insulin, and 4 were either inoperable or refused surgery, the diagnosis being proven at autopsy. Accordingly, follow-up samples were available in only 14 patients. Furthermore, in the preoperative period, 6 patients received rapid iv glucose loading ( $0.5 \mathrm{~g}$ glucose per $\mathrm{kg}$ of body weight) with samples for serum ILA drawn before, and 10,20, and 60 minutes after infusion. Blood specimens were allowed to clot at room temperature, and the serum was separated by centrifugation. Serum glucose was determined on sample by the Somogyi-Nelson method $(5,6)$, and the remainder was kept frozen at $-20^{\circ} \mathrm{C}$ for bioassay.

Portions of the islet-cell tumors were collected either immediately after surgical removal of the tumor, or at autopsy, and were quickly frozen. Adjacent pancreas, or metastatic tissue, or both were obtained and stored similarly. For control purposes, pancreas from nondiabetic subjects, and youth-onset and maturity-onset diabetic patients were obtained at autopsy 6 hours or less after death and treated in an identical manner. Insulin extraction of all tissues was performed in the cold by the acid ethanol technique (7), or by a cationic exchange resin method, or both. The resin employed was Dowex $50 \mathrm{~W}-\mathrm{X} 2$ which was prepared fresh each week as previously described (8). The frozen tissue was homogenized for 3 to 5 minutes in a Waring Blendor, with $10 \mathrm{ml}$ of cold saline added for each gram of tissue. The homogenate was pressed through cheesecloth, and the filtrate was collected in a beaker already containing $20 \mathrm{ml}$ of prepared

1 We gratefully acknowledge the collaboration of Drs. F. N. Allen, D. B. Claudon, Y. M. Dagenais, R. A. Field, N. F. Freinkel, G. Gosselin, S. Hashim, A. Marble, L. J. Marks, L. S. McKittrick, M. L. Mitchell, M. K. Mookerjee, F. D. Moore, W. I. Morse, R. Murphy, A. E. Overstreet, D. C. Pennoyer, R. E. Randall, Jr., P. Pitchette, H. F. Root, J. J. Rupp, D. Singer, G. H. Sprecace, L. Steinberg, J. E. Thompson, G. W. Thorn, T. Van Itallie, and $\mathrm{K}$. W. Warren. 
resin per gram of tissue. The mixture was stirred for 5 minutes, the resin allowed to settle, the upper phase decanted, and the resin washed three times with $100 \mathrm{ml}$ of cold saline. The supernatant fluids were pooled and measured, and a sample was frozen and designated the "resin-nonadsorbable insulin fraction." Subsequently, 2 $\mathrm{ml}$ of $0.1 \mathrm{~N}$ sulfuric acid was added per milliliter of resin and stirred for 15 minutes. This was decanted and the resin washed once with $100 \mathrm{ml}$ of cold saline. Then $1.5 \mathrm{ml}$ of $1 \mathrm{~N} \mathrm{NH} \mathrm{N}_{4} \mathrm{OH}$ per milliliter of resin was added, stirred for exactly 5 minutes, allowed to settle, and decanted. A $100-\mathrm{ml}$ vol of cold saline was added to the resin, stirred for 2 minutes, and the mixture filtered through cheesecloth. The acid and the alkaline eluates and washes were combined, the $\mathrm{pH}$ was immediately adjusted to 2.8 , the volume measured, and a sample frozen and designated the "resin-adsorbable insulin fraction." Both the resinadsorbable and the resin nonadsorbable insulin fractions were assayed for insulin content. The ratio between the two appeared to be fairly constant, as previously reported (9). To estimate total extractable insulin content by this resin method, the values obtained for each fraction were combined, and this sum is referred to as "total resinextractable insulin."
All sera and tissue extracts were assayed for ILA with rat epididymal adipose tissue, with the oxidation of glucose-1- $\mathrm{C}^{14}$ to $\mathrm{C}^{14} \mathrm{O}_{2}$ the index of activity (10). Most serum samples were assayed at various dilutions with buffer, all tissue samples were assayed at four different dilutions, and all final values were corrected for the respective dilution. Each assay was assessed statistically (11), and those with an index of precision above 0.30 were repeated. In more recent assays, collection of $\mathrm{C}^{14} \mathrm{O}_{2}$ was adapted to liquid scintillation counting (12).

\section{RESULTS}

Data on the 23 patients with islet-cell tumors are shown in Table I. Fifteen were women, mean age 50 years, and 8 were men, mean age 53 years. The youngest patient was 25 and the oldest, 86 years old. An islet-cell tumor developed in one patient ( $\mathrm{O}^{\prime} \mathrm{N}$ ) who had pre-existing diabetes mellitus (4). Acromegaly was present in FIN and $\mathrm{PRO} ; \mathrm{FIN}$ was seen with a recurrence of an islet-cell tumor reported previously (13). GRO

TABLE I

Mean serum glucose and mean serum insulin-like activity (ILA) of patients with islet-cell tumors before and after surgery*

\begin{tabular}{|c|c|c|c|c|c|c|c|c|}
\hline \multirow[b]{2}{*}{ Patient } & \multirow[b]{2}{*}{ Sex } & \multirow[b]{2}{*}{ Age } & \multicolumn{3}{|c|}{ Preoperative } & \multicolumn{3}{|c|}{ Postoperative } \\
\hline & & & $\begin{array}{l}\text { No. of serum } \\
\text { samples }\end{array}$ & $\begin{array}{c}\text { Mean } \\
\text { serum } \\
\text { glucose }\end{array}$ & $\underset{\text { ILA }}{\text { Merum }}$ & $\begin{array}{l}\text { No. of serum } \\
\text { samples }\end{array}$ & $\begin{array}{c}\text { Mean } \\
\text { serum } \\
\text { glucose }\end{array}$ & $\underset{\text { ILA }}{\text { Mean }}$ \\
\hline \multirow{27}{*}{$\begin{array}{l}\text { MOR } \\
\text { CIA } \\
\text { FIN } \\
\text { COH } \\
\text { WAR } \\
\text { MAR } \\
\text { PRO† } \\
\text { LOG } \\
\text { FLA } \\
\text { SAV† } \\
\text { LAU } \\
\text { GRO† } \\
\text { GAN } \\
\text { HAM } † \\
\text { ON† } \\
\text { O'B† } \\
\text { FOT } † \\
\text { DON } \\
\text { LOM } \\
\text { LEA } \\
\text { ANG } \\
\text { COM } \\
\text { CEC } †\end{array}$} & & years & & $m g / 100 \mathrm{ml}$ & $\mu U / m l$ & & $\mathrm{mg} / 100 \mathrm{ml}$ & $\mu U / m l$ \\
\hline & $\mathrm{F}$ & 45 & 1 & 88 & 2,000 & & & \\
\hline & $\mathbf{M}$ & 70 & 1 & 30 & 1,510 & 1 & 96 & 130 \\
\hline & $\mathrm{F}$ & 57 & 2 & 5 & 1,450 & 3 & 101 & $1,120 \ddagger$ \\
\hline & $\mathbf{M}$ & 62 & 2 & 30 & 1,280 & & & \\
\hline & $\mathbf{M}$ & 52 & 2 & 17 & 1,210 & 2 & 20 & $780 t$ \\
\hline & $\mathrm{F}$ & 37 & 2 & 42 & 1,030 & $\overline{1}$ & 120 & $150^{+}$ \\
\hline & $\mathrm{F}$ & 49 & 3 & 14 & 1,010 & & & \\
\hline & $\mathbf{M}$ & 38 & 2 & 65 & 920 & 4 & 87 & 680 \\
\hline & $\mathrm{F}$ & 80 & $\overline{1}$ & 16 & 880 & & & \\
\hline & $\mathbf{M}$ & 45 & 1 & 38 & 870 & 1 & 78 & $720 \S$ \\
\hline & $\mathrm{F}$ & 36 & 1 & 54 & 860 & 2 & 98 & $360^{\circ}$ \\
\hline & $\mathrm{F}$ & 48 & 1 & 14 & 830 & 1 & 32 & $440 \ddagger$ \\
\hline & $\mathbf{M}$ & 45 & 1 & 15 & 720 & & & \\
\hline & $\mathrm{F}$ & 56 & 1 & 15 & 710 & 1 & 129 & 450 \\
\hline & $\mathbf{M}$ & 57 & 5 & 35 & 700 & & & $\ddagger$ \\
\hline & $\mathbf{M}$ & 50 & 2 & 43 & 690 & & & \\
\hline & $\mathrm{F}$ & 43 & 2 & 45 & 610 & 4 & 105 & 380 \\
\hline & $\mathrm{F}$ & 45 & 2 & 68 & 510 & 2 & 63 & 130 \\
\hline & $\mathrm{F}$ & 60 & 1 & 45 & 450 & 1 & 90 & 130 \\
\hline & $\mathrm{F}$ & 86 & 1 & 35 & 440 & & & \\
\hline & $\mathrm{F}$ & 42 & 1 & 56 & 384 & 1 & 85 & 348 \\
\hline & $\mathrm{F}$ & 25 & 6 & 42 & 362 & 4 & 64 & 497 \\
\hline & $\mathrm{F}$ & 43 & 1 & 27 & 280 & & & \\
\hline & & & Mean $(n=23)$ & 35 & 900 & Mean $(n=10)$ & 94 & 325 \\
\hline & & & SD & \pm 21 & \pm 410 & $\mathrm{SD}$ & \pm 21 & \pm 189 \\
\hline & & & $\mathrm{SE}$ & \pm 5 & \pm 89 & SE & \pm 7 & \pm 60 \\
\hline
\end{tabular}

* Postoperative serum samples were obtained 7 or more days after surgery. Values from patients with postoperative insulin treatment or incomplete resection of tumor were excluded from the postoperative mean.

$\dagger$ Tumor tissue available for insulin extraction (10 patients).

$\$$ Islet-cell tumor with metastases (6 patients).

Multiple pancreatic islet-cell tumors (1 patient). 
TABLE II

Incidence of hypoglycemia associated with highest value of serum ILA in each of 23 patients with islet-cell tumors $(I C T)^{*}$

\begin{tabular}{|c|c|c|c|}
\hline \multirow[b]{2}{*}{$\begin{array}{c}\text { Range of } \\
\text { ILA }\end{array}$} & \multicolumn{2}{|c|}{$\begin{array}{c}\text { Distribution of } \\
\text { highest indi- } \\
\text { vidual serum ILA }\end{array}$} & \multirow{2}{*}{$\begin{array}{l}\text { No. of serum } \\
\text { glucose values } \\
\text { below } 40 \mathrm{mg} \\
\text { per } 100 \mathrm{ml} \text { in } \\
\text { the ICT groupt }\end{array}$} \\
\hline & $\begin{array}{l}\text { Control } \\
\text { subjects }\end{array}$ & $\begin{array}{l}\text { Patients } \\
\text { with } \\
\text { ICT }\end{array}$ & \\
\hline \multicolumn{4}{|l|}{$\mu U / m l$} \\
\hline$<500$ & 100 & 4 & 2 \\
\hline $500-1,000$ & 18 & 10 & 7 \\
\hline$>1000$ & 0 & 9 & 7 \\
\hline Total & 118 & 23 & 16 \\
\hline
\end{tabular}

* For comparison, the distribution of serum ILA levels in 118 controls is also given. $40 \mathrm{mg}$ per $100 \mathrm{~m}$

exhibited multiple endocrine adenomata (anterior lobe of pituitary, adrenals, and all four parathyroids). In COM, the islet-cell tumor was diagnosed and removed during pregnancy.

The mean serum glucose of the 23 patients before surgery was $34 \mathrm{mg}$ per $100 \mathrm{ml}$, and in 10 patients after successful surgery, it was $94 \mathrm{mg}$ per $100 \mathrm{ml}$. Serum ILA showed a wide preoperative range, with a mean of $900 \mu \mathrm{U}$ per ml. After complete removal of the tumor in 10 patients, the mean fell to $325 \mu \mathrm{U}$ per $\mathrm{ml}$. Of these 10 patients, 8 showed a significant decrease in serum ILA, whereas 2 exhibited no change. Excluded from the postoperative mean serum glucose and serum ILA are 3 patients with functioning islet-cell tumor metastases and one patient (SAV) with incompletely resected, multiple, pancreatic islet-cell tumors. As a group, the preoperative mean serum ILA was significantly higher than either the postoperative mean, or the mean of normal controls fasted overnight.

Table II shows the highest preoperative serum ILA in each of the 23 patients and for comparison includes 118 normal control values obtained after an overnight fast. Since the mean of the normal values was $277 \mu \mathrm{U}$ per ml, with a standard deviation of $206 \mu \mathrm{U}$ per ml, and since none of the normal values exceeded $1,000 \mu \mathrm{U}$ per $\mathrm{ml}, 500$ and $1,000 \mu \mathrm{U}$ were chosen as dividing lines. Thus, each person's highest serum ILA was assigned to one of the following three ranges: below 500, between 500 and 1,000 , and above $1,000 \mu \mathrm{U}$ per $\mathrm{ml}$. Also shown are the number of sera in each category with a corresponding serum glucose concentration below $40 \mathrm{mg}$ per $100 \mathrm{ml}$. In 9 of 23 patients, serum ILA exceeded $1,000 \mu \mathrm{U}$ per $\mathrm{ml}$, a value never found in the 118 normal controls. In 10 of 23 patients, serum ILA ranged between 500 and $1,000 \mu \mathrm{U}$ per ml, overlapping with 18 of

TABLE III

Insulin extractable by acid ethanol $(A E)$ or cationic exchange resin $(C E R)$ procedures from islet-cell tumors, adjacent pancreas, and tissues with metastases, as estimated by rat adipose tissue bioassay

\begin{tabular}{|c|c|c|c|c|c|c|}
\hline \multirow[b]{2}{*}{ Patient } & \multirow{2}{*}{$\begin{array}{c}\text { Available } \\
\text { tumor }\end{array}$} & \multirow{2}{*}{$\begin{array}{c}\text { Extraction } \\
\text { procedure }\end{array}$} & & \multicolumn{3}{|c|}{ Insulin extractable } \\
\hline & & & & Tumor & Other tissues & \\
\hline & $g$ & & & $U / \mathrm{g}$ tumor & & $U / g$ tissue \\
\hline CEC & 2.00 & $\mathrm{AE}$ & & 60.0 & Adjacent pancreas & 1.91 \\
\hline SAV & 2.40 & $\mathrm{AE}$ & & $56.0^{*}$ & $\begin{array}{l}\text { Pancreas together with } \\
\text { adenoma }\end{array}$ & 25.00 \\
\hline PRO & 0.17 & CER & & 29.0 & & \\
\hline FOT & 0.15 & CER & & 7.8 & & \\
\hline HAM & 1.40 & CER & & 5.0 & Adjacent pancreas & 0.09 \\
\hline GRO & 3.00 & CER & & $3.7 \dagger$ & Metastasic lymph node & 2.20 \\
\hline FIN & 1.70 & CER & & $3.2 \dagger$ & Adjacent pancreas & 0.09 \\
\hline O'B & 9.00 & $\mathrm{AE}$ & & $2.6 \dagger$ & & \\
\hline GAN & 1.80 & CER & & $2.3 \dagger$ & & \\
\hline $\mathrm{O}^{\prime} \mathrm{N}$ & 0.50 & CER & & $0.8 \dagger$ & $\begin{array}{l}\text { Pancreas with metastasis } \\
\text { Liver with metastasis } \\
\text { Isolated liver metastasis }\end{array}$ & $\begin{array}{l}0.25 \\
0.02 \\
0.12\end{array}$ \\
\hline$(n=10)$ & & & $\begin{array}{l}\text { Mean } \\
\text { SEM }\end{array}$ & $\begin{array}{r}17.0 \\
7.2\end{array}$ & & \\
\hline
\end{tabular}

* Multiple pancreatic islet-cell tumors.

$\dagger$ Islet-cell tumor with metastasis. 


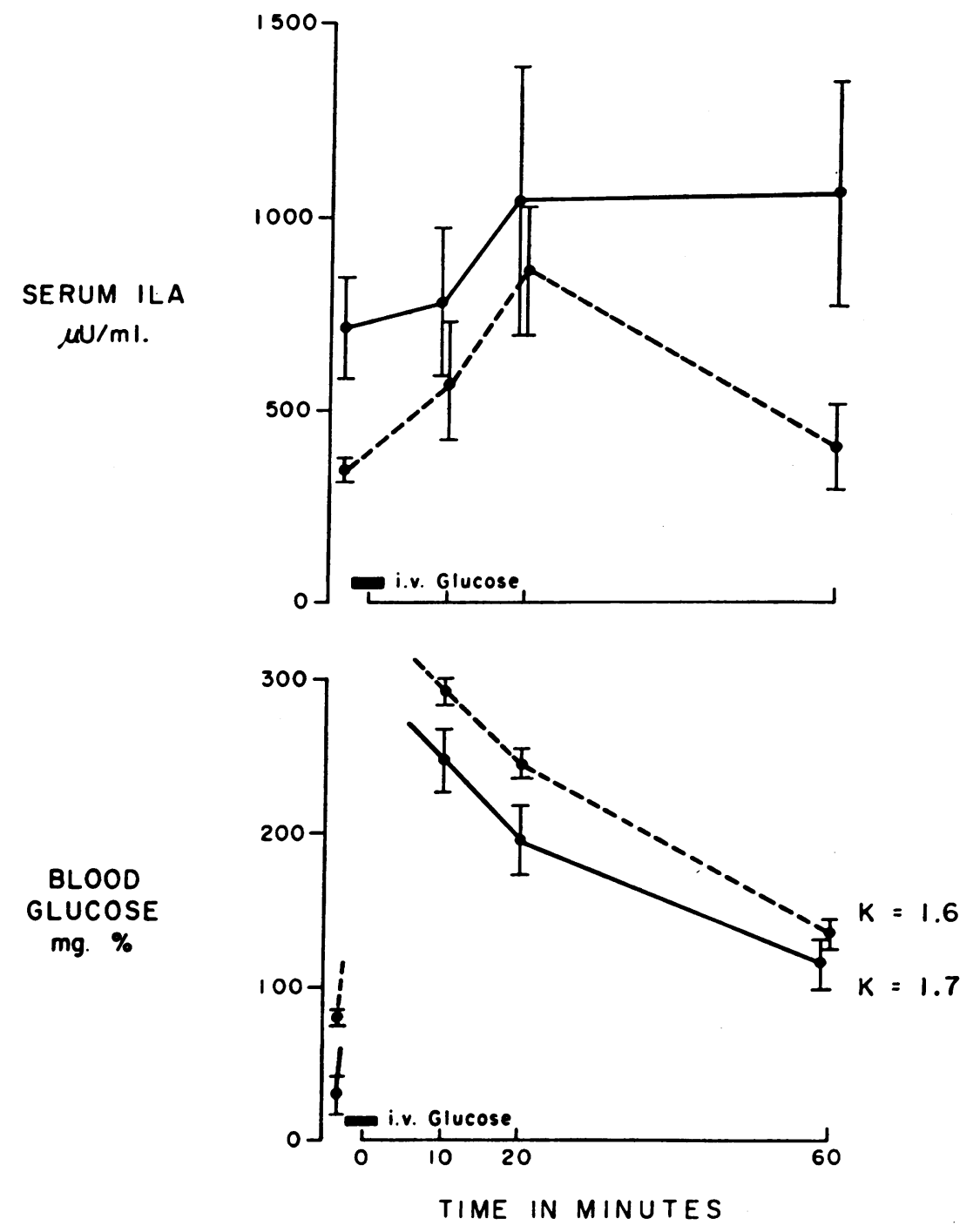

Fig. 1. SERUM INSULIN-LIKE ACTIVITY (ILA) AND BLOOD GLUCOSE AFTER RAPID IV GLUCOSE ADMINISTRATION (0.5 G PER KG BODY WEIGHT) IN 6 PATIENTS WITH ISLET-CELL TUMOR (-) AND IN 12 NORMAL CONTROLS (-- ) (MEAN \pm SE). $\mathrm{K}=$ glucose disappearance rate.

the 118 normal controls. Only 4 of the 23 patients had serum ILA below $500 \mu \mathrm{U}$ per $\mathrm{ml}$, as compared with 100 of the 118 normal control sera. In general, in the islet-cell tumor patients, higher values of serum ILA corresponded to lower values of serum glucose, although this was not true in approximately one-third of the samples tested.

Figure 1 depicts the change from fasting serum ILA after iv glucose infusion and compares 6 islet-cell tumor patients with 12 normal controls. The control group showed an initial rise at 10 minutes that became significant at 20 minutes, when a threefold increase above base line was observed; there was a return to base line at 60 minutes. Patients with islet-cell tumors showed no significant rise either at 10 , or at 20 minutes. The absolute mean fasting value, however, of the serum from islet-cell tumor patients $(705 \mu \mathrm{U}$ per $\mathrm{ml})$ was significantly higher than that of the controls $(345 \mu \mathrm{U}$ per $\mathrm{ml}$ ). This was also true 60 minutes after the glucose infusion, when serum ILA in the control subjects had returned to base line.

The extractable insulin content of 10 islet-cell 
TABLE IV

Insulin extractable by both acid ethanol $(A E)$ and cationic exchange resin (CER) procedures from samples of the same pancreas of nondiabetic, youth-onset diabetic, and maturity-onset diabetic subjects, as estimated by rat adipose tissue bioassay

\begin{tabular}{|c|c|c|c|c|c|c|}
\hline \multirow{3}{*}{$\begin{array}{c}\text { Subject: } \\
\text { no: } \\
\text { Extraction } \\
\text { procedure: }\end{array}$} & \multicolumn{2}{|c|}{ Nondiabetic } & \multicolumn{2}{|c|}{ Youth-onset DM } & \multicolumn{2}{|c|}{ Maturity-onset DM } \\
\hline & \multicolumn{2}{|c|}{10} & \multicolumn{2}{|c|}{6} & \multicolumn{2}{|c|}{7} \\
\hline & CER & $\mathrm{AE}$ & CER & $\mathrm{AE}$ & CER & $\mathrm{AE}$ \\
\hline & \multicolumn{2}{|c|}{$U / g$ pancreas } & \multicolumn{2}{|c|}{$U / g$ pancreas } & \multicolumn{2}{|c|}{$U / g$ pancreas } \\
\hline & 3.9 & 3.1 & 0.08 & 0.10 & 1.5 & 0.8 \\
\hline & 3.6 & 2.9 & 0.07 & 0.01 & 1.3 & 1.1 \\
\hline & 2.9 & 2.4 & 0.06 & 0.09 & 1.3 & 1.6 \\
\hline & 2.6 & 1.9 & 0.06 & 0.04 & 1.1 & 1.0 \\
\hline & 2.0 & 1.6 & 0.04 & 0.02 & 1.1 & 1.7 \\
\hline & 1.7 & 1.9 & 0.03 & 0.02 & 0.7 & 0.5 \\
\hline & 1.5 & 1.5 & & & 0.5 & 1.1 \\
\hline & 1.2 & 1.0 & & & & \\
\hline & 1.1 & 0.8 & & & & \\
\hline & 1.0 & 1.1 & & & & \\
\hline Mean & 2.15 & 1.82 & 0.06 & 0.05 & 1.07 & 1.11 \\
\hline SEM & \pm 0.33 & \pm 0.24 & \pm 0.03 & \pm 0.02 & \pm 0.14 & \pm 0.15 \\
\hline
\end{tabular}

tumors by either acid ethanol or resin procedure is shown in Table III. Values ranged from 60 to $0.8 \mathrm{U}$ per $\mathrm{g}$ wet weight, with a mean value of 17 . The 5 lowest values belonged to patients with metastases. Unfortunately, in none of the 10 tumors was total tumor weight available, and therefore no statement can be made about the relationship between tumor size and insulin content, although our impression was that the higher values were found in the smaller tumors. In this report, no distinction was made between islet-cell adenoma and low-grade carcinoma, as determined histologically. Instead, the tumors were classified according to presence or absence of metastases. Pancreatic tissue adjacent to the tumor contained $0.09 \mathrm{U}$ per gram in two patients and $1.9 \mathrm{U}$ per gram in a third. Metastatic lesions in liver and lymph nodes contained extractable insulin, whereas normal lymph nodes and normal liver did not (data not shown).

Comparisons of the two insulin extraction procedures on samples from the same pancreas are shown in Table IV. This includes pancreases from 10 nondiabetic patients, as well as from 6 youth-onset and 7 maturity-onset diabetic patients.

\section{DISCUSSION}

There have been previous reports of serum insulin ILA in patients with proven islet-cell tumor. Despite the variety of assays employed, in reports based on a sufficiently large series of observations, the presence of an islet-cell tumor is not necessarily associated with elevated values of serum insulin or ILA. Using glucose uptake by rat hemidiaphragm as an index of activity, Willebrands, Groen, Van der Geld, and Bolinger (14, 15) reported elevated levels in 9 of 16 patients, and Wright (16), in 3 of 7 . Using an immunoassay, Berson and Yalow (17) showed high fasting values of plasma insulin in 7 of 15 patients, and similar findings were reported recently by Samols and Marks (18). Data obtained with the rat adipose tissue assay are scarce and furthermore have been procured with different indexes of ILA. Bürgi and co-workers (19), using glucose uptake and net gas production as index of ILA, reported values for 6 patients, 2 of which were above the normal range for that method. Pfeiffer, Pfeiffer, Ditschuneit, and Ahn (20), using $\mathrm{C}^{14} \mathrm{O}_{2}$ production from glucose-1- $\mathrm{C}^{14}$ as index of ILA, reported on one patient whose serum ILA was grossly elevated.

The data presented in this report were obtained by use of oxidation of glucose-1- $\mathrm{C}^{14}$ to $\mathrm{C}^{14} \mathrm{O}_{2}$ as index of ILA. In 23 patients with islet-cell tumors, 9 showed values above $1,000 \mu \mathrm{U}$ per $\mathrm{ml}$. Of the 118 normal control sera similarly tested, none showed this high a value. The 14 remaining patients had a range of values encountered in control sera. Only $5(22 \%)$ of the islet cell tumor patients, however, had values below $500 \mu \mathrm{U}$ per $\mathrm{ml}$, as compared with $85 \%$ for the normogly- 
cemic control subjects. As shown in Tables I and II, the probability of finding elevated levels of serum ILA in patients with islet-cell tumors did not increase when multiple serum samples were tested, even when they were obtained during severe hypoglycemia.

The data presented here agree with the literature that the determination of serum insulin is of limited value in assessing individual patients, regardless of the method of insulin assay used. To account for this is difficult. It is conceivable that a low normal value for serum insulin before the development of the islet-cell tumor could be greatly increased, but still be within the wide normal range. Such a possibility was suggested in two of our patients whose preoperative values were below $500 \mu \mathrm{U}$ per ml. After surgery, they exhibited a decrease from just below 500 to $100 \mu \mathrm{U}$ per $\mathrm{ml}$. Two other patients in our group, however, with similar preoperative values failed to show a significant change after surgery. To our knowledge, neither of the two had recurrence of hypoglycemic episodes.

Failure of isolated fasting values for serum ILA to aid in the diagnosis of islet-cell tumor in all instances led us to test in serial samples the response of serum ILA to a rapid iv glucose load. Whereas 12 normal subjects showed a significant increase, most marked at 20 minutes after infusion, the change in serum ILA in 6 patients with islet-cell tumor was random. When absolute values were compared, the mean fasting level of the islet-cell tumor group was reached by the normal group 20 minutes after glucose loading, implying close to maximal insulin output by the former. The potential diagnostic value of this observation, however, is impaired by the observation of a similar pattern of serum ILA in response to glucose in patients with early diabetes and in those with prediabetes (12).

Whether or not the rat epididymal adipose tissue bioassay used in these studies measures only serum insulin, or also substances closely related to it is still unclear, a limitation of this bioassay that we have pointed out (21). The overlap between values obtained in patients with islet-cell tumors and normal fasting subjects, however, is approximately the same with this bioassay as with the rat hemidiaphragm bioassay $(15,16)$, or the immunoassay $(17,18)$.
Few publications have presented data on extractable insulin content of islet-cell tumors. Wilder, Allan, and Robertson (22) in 1927 demonstrated insulin content in a metastatic nodule located in the liver and reported $4 \mathrm{U}$ per $\mathrm{g}$ of tissue, an order of magnitude confirmed by Judd, Faust, and Dixon (23) in a different patient. A tumor extracted and measured by Grodsky and Forsham (24) contained $15 \mathrm{U}$ per $\mathrm{g}$, one reported by Johnston, Goetz, and Zimmerman (25) had $20 \mathrm{U}$ per g, and one evaluated by Ball and Merrill (26), $81 \mathrm{U}$ per $\mathrm{g}$.

In the present series, values obtained with 10 different tumors ranged from 0.8 to $60 \mathrm{U}$ per $\mathrm{g}$ wet weight. The lowest value was obtained in tissue from a patient whose islet-cell tumor was preceded by diabetes mellitus. Values lower than $3.7 \mathrm{U}$ per $\mathrm{g}$ were obtained in all primary tumors with functioning metastases. The highest values are below the insulin content of the giant islet of the toadfish (27) (140 U per $\mathrm{g}$ wet weight) and below values reported by Lacy and Williamson (28) for the dissected beta cells from the normal rabbit pancreas (about 1,200 U per $g$ wet weight). The insulin concentration of islet-cell tumors ranges from that of pancreatic tissue to that of pure islet-cell preparations. Of interest is the low extractable insulin content in pancreas adjacent to the tumor in two of three specimens obtained. Depression of the remaining normal pancreatic insulin due to hyperinsulinism in the presence of an islet-cell tumor could explain impaired glucose tolerance and transient diabetes after the removal of islet-cell tumors. We could confirm earlier findings by Wilder and associates and by Judd and associates of extractable insulin from functioning islet-cell tumor metastases by metastases to lymph node and liver.

For control of the two extraction techniques employed, a comparison was obtained on extractable insulin content of pancreas from nondiabetic controls as well as from patients with youth-onset and maturity-onset diabetes. Our data show good agreement between the two techniques and confirm earlier work by Wrenshall, Bogoch, and Ritchie (29) and by Jorpes and Rastgeldi (30).

\section{SUM MARY}

1. Serum insulin-like activity (ILA) in epididymal rat adipose tissue was measured in 23 
patients with histologically confirmed islet-cell tumors. The mean serum ILA of these patients was significantly greater than that of 118 control subjects, and the values obtained in 9 patients exceeded the full normal range. Postoperative values were obtained in 10 patients without recognizable recurrence or metastases. All of these postoperative values were within the normal range, and in 8 instances, the individual decrease observed was significant; it was not significant in the other two patients. These data agree with previous reports employing either the rat hemidiaphragm bioassay for insulin activity or the immunoassay procedure. Measurements of serum insulin or ILA are diagnostic in approximately one-third of the patients with islet-cell tumors.

2. Patients with islet-cell tumors showed no significant change in serum ILA after rapid intravenous glucose loading, whereas normal subjects exhibited a threefold increase in serum ILA 20 minutes after the infusion of glucose.

3. The insulin content of 10 islet-cell tumors was determined, and varied from 0.8 to $60 \mathrm{U}$ per $g$ wet weight. There was no apparent relationship between tumor insulin concentration and preoperative serum ILA. Islet-cell tumors with functioning metastases had lower tumor insulin concentration than tumors without metastases.

4. For comparison and for control of the acid ethanol and the resin extraction techniques used in these studies, insulin content of pancreases obtained at autopsy was determined in 10 nondiabetic and 13 diabetic subjects. The values obtained showed close agreement between the two techniques, as well as with published data.

\section{ACKNOWLEDGMENTS}

We are indebted to Dr. Harry N. Antoniades for helpful advice regarding the cationic exchange resin technique, and we gratefully acknowledge the expert technical assistance of Mrs. Marta Grinbergs, Mrs. Maija Grinbush, and Miss Josette C. Leuba.

\section{REFERENCES}

1. Moss, N. H., and J. E. Rhoads. Hyperinsulinism and islet cell tumors of the pancreas. Surgical Diseases of the Pancreas, J. M. Howard and G. L. Jordan, Eds. Philadelphia, Lippincott, 1960, p. 321.

2. Sprecace, G. H., D. C. Pennoyer, and J. E. Thompson. Functioning islet-cell carcinoma of the pancreas. Postgrad. Med. 1961, 30, 36.
3. Overstreet, A. E., and J. J. Rupp. Functioning islet cell adenoma with a note about leucine sensitivity. Ann. intern. Med. 1961, 55, 998.

4. Mahon, W. A., M. L. Mitchell, J. Steinke, and M. S. Raben. Effect of human growth hormone on hypoglycemic states. New Engl. J. Med. 1962, 267, 1179.

5. Somogyi, M. Determination of blood sugar. J. biol. Chem. 1945, 160, 69.

6. Nelson, N. A photometric adaptation of the Somogyi method for the determination of glucose. J. biol. Chem. 1944, 153, 375.

7. Scott, D. A., and A. M. Fisher. The insulin and the zinc content of normal and diabetic pancreas. J. clin. Invest. 1938, 17, 725.

8. Atoniades, H. N., A. E. Renold, Y. M. Dagenais, and J. Steinke. Preliminary observations on state of insulin in human and bovine pancreas. Proc. Soc. exp. Biol. (N. Y.) 1960, 103, 677.

9. Steinke, J., A. E. Renold, J. Knaack, and H. N. Antoniades. Insulin content of pancreas from nondiabetic and diabetic subjects and from pancreatic islet cell tumors, as extracted on cationic exchange resin and with acid ethanol (abstract). J. clin. Invest. 1961, 40, 1083.

10. Renold, A. E., D. B. Martin, Y. M. Dagenais, J. Steinke, R. J. Nickerson, and M. C. Sheps. Measurement of small quantities of insulin-like activity using rat adipose tissue. I. A proposed procedure. J. clin. Invest. 1960, 39, 1487.

11. Sheps, M. C., R. J. Nickerson, Y. M. Dagenais, J. Steinke, D. B. Martin, and A. E. Renold. Measurement of small quantities of insulin-like activity using rat adipose tissue. II. Evaluation of performance. J. clin. Invest. 1960, 39, 1499.

12. Steinke, J., J. S. Soeldner, R. Camerini Davalos, and A. E. Renold. Studies on serum insulin-like activity (ILA) in prediabetes and early overt diabetes. Diabetes. In press.

13. Crain, E. L., G. W. Thorn, and F. Moore. Acromegaly with coexisting insulinomas, case report. Proc. Amer. Diabetes Ass. 1949, 9, 373.

14. Willebrands, A. F., and J. Groen. Determination of serum insulin by the rat diaphragm method. Further observations in diabetic and nondiabetic subjects and in hyperinsulinism. Diabetes 1956, 5, 378.

15. Groen, J., A. F. Willebrands, H. G. Van der Geld, and R. E. Bolinger. Determination of serum insulin in patients with islet cell tumors of the pancreas in Hormone Production in Endocrine Tumors, Ciba Foundation Coll. Endocr., G. E. Wolstenholme and M. O'Connor, Eds. Boston, Little, Brown, 1958, vol. 12, p. 255.

16. Wright, P. H. Plasma-insulin activity in acromegaly and spontaneous hypoglycaemia. Lancet 1960, 1, 951.

17. Berson, S. A., and R. S. Yalow. Immunoassay of plasma insulin in Immunoassay of Hormones, 
Ciba Foundation Coll. Endocr., G. E. Wolstenholme and M. P. Cameron, Eds. Boston, Little, Brown, 1962, vol. 14, p. 183.

18. Samols, E., and V. Marks. Insulin assay in insulinomas. Brit. Med. J. 1963, 1, 507.

19. Bürgi, H., E. B. Ramseier, E. R. Froesch, P. Bally, and A. Labhart. «Freies» und «gebundenes» Insulin im Serum von Patienten mit B-Inselzell-adenom. Helv. med. Acta 1962, 29, 527.

20. Pfeiffer, E. F., M. Pfeiffer, H. Ditschuneit, and C-S Ahn. Uber die Bestimmung von Insulin im Blute am epididymalen Fettanhang der Ratte mit Hilfe markierter Glucose. Klin. Wschr. 1959, 37, 1239.

21. Steinke, J., A. Sirek, V. Lauris, F. D. W. Lukens, and A. E. Renold. Measurement of small quantities of insulin-like activity with rat adipose tissue. III. Persistence of serum insulin-like activity after pancreatectomy. J. clin. Invest. 1962, 41, 1699.

22. Wilder, R. M., H. N. Allan, and H. E. Robertson. Hyperinsulinism from carcinoma of the islands of Langerhans (abstract). J. clin. Invest. 1927, 4, 436.

23. Judd, E. S., L. S. Faust, and R. K. Dixon. Carcinoma of the islands of Langerhans with metastasis to liver producing hyperinsulinism, report of a case. West. J. Surg. 1934, 42, 555.

24. Grodsky, G. M., and P. H. Forsham. An immunochemical assay of total extractable insulin in man. J. clin. Invest. 1960, 39, 1070.

25. Johnston, R., F. C. Goetz, and B. Zimmerman. Insulin secreting tumor of the pancreas. New Engl. J. Med. 1960, 260, 1345.

26. Ball, E. G., and M. A. Merrill. A manometric assay of insulin and some results of the application of the method to sera and islet-containing tissue. Endocrinology 1961, 69, 596.

27. Humbel, R. E., A. E. Renold, M. G. Herrera, and K. W. Taylor. Incorporation of glucose carbon into protein of the islets of Langerhans from toadfish (Opsanus tau). Endocrinology 1961, 69, 874.

28. Lacy, P. E., and J. R. Williamson. Quantitative histochemistry of the islets of Langerhans. II. Insulin content of dissected beta cells. Diabetes 1962, 11, 101.

29. Wrenshall, G. A., A. Bogoch, and R. C. Ritchie. Extractable insulin of pancreas. Diabetes 1952, 1, 87.

30. Jorpes, E., and S. Rastgeldi. The insulin content of human pancreas. Acta physiol. scand. 1953, 29, 163. 